Ind. Health, 1970, 8, 184.

\title{
PREVENTIVE EFFECT OF PRETREATMENT WITH LOW DOSE OF METALS ON THE ACUTE TOXICITY OF METALS IN MICE
}

\author{
Hiroshi YOSHIKAWA \\ National Institute of Industrial Health, Kizuki-Sumiyoshi, Kawasaki
}

(Received September, 14, 1970)

\begin{abstract}
In a previous short communication, it was reported that mice injected with small amounts of metals tolerated the lethal dosage of the same metals given $24 \mathrm{hs}$ later. The present study was designed to obtain the precise information on the tolerance to the acute toxicity of various kinds of metals. This tolerance was determined by the difference of mortality between the mice given the lethal doses of metals with and without pretreatment.

From the results of this experiment, it was found that metals were divided into 3 groups as follows :

Group I: Metals with which the mortality caused by challenge are reduced with pretreatment. These metals which can develop a tolerance against their own toxic action are $\mathrm{Ag}, \mathrm{As}, \mathrm{Cd}, \mathrm{Hg}, \mathrm{In}, \mathrm{Pb}, \mathrm{Mn}$, and $\mathrm{Sn}$.

Group II : Metals with which their pretreatment had no effect on mortality caused by challenging are $\mathrm{Cu}, \mathrm{Ni}$, Se, and $\mathrm{Tl}$.

Group III : Metals with which pretreatment increased their mortality and these metals became more toxic by pretreatment: $\mathrm{Ba}, \mathrm{Cr}, \mathrm{Fe}$, and $\mathrm{Zn}$.

From these results, it can be concluded that pretreated mice show a tolerance to the toxic action of most of contaminant metals and do not to that of essential metals.

Moreover, it was found that metals belonging to Group I have the ability to develop a cross-tolerance while those of Group II and III do not.
\end{abstract}

Recently the effect of some metals ${ }^{1 \sim 11)}$ on the toxicity of simultaneously administered metals and on a metal shift ${ }^{12 \sim 15)}$ in the body poisoned with toxic substances have been reported. In the previous report, ${ }^{16)}$ it was recognized that the effect of pretreatment with small dose of metal upon acute metal toxicity was divided into 3 groups, that is, metals with which pretreatment of mice reduced the mortality from challenging with the same metals, metals with which the pretreatment of mice has no effect in mortality, and metals with which the pretreatment caused an increase in mortality.

Moreover, it was found that some metals have an ability to promote a crosstolerance.

This experiment was performed to study the tolerance problem more precisely 


\section{EFFECT OF PRETREATMENT ON METAL TOXICITY}

on various kind of metals.

\section{METHODS}

Male ICR mice fostered by the pellet food by The Nippon Clea Co. Ltd. and tap water were used as experimental animals.

Metal compounds used in this experiment were $\mathrm{AgNO}_{3}, \mathrm{NaAsO}_{2}, \mathrm{BaCl}_{2}, \mathrm{CdCl}_{2}$, $\mathrm{CrCl}_{3}, \mathrm{CuSO}_{4}, \mathrm{FeSO}_{4}, \mathrm{HgCl}_{2}, \mathrm{In}_{2}\left(\mathrm{SO}_{4}\right)_{3}, \mathrm{MnCl}_{2}, \mathrm{NiCl}_{2}, \mathrm{~Pb}\left(\mathrm{NO}_{3}\right)_{2}, \mathrm{Na}_{2} \mathrm{SeO}_{4}, \mathrm{SnCl}_{4}, \mathrm{TlNO}_{3}$, and $\mathrm{ZnSO}_{4}$. These compounds were dissolved in distilled water.

Tolerance which might be induced by pretreatment was measured by differences in mortality from subsequent injection of challenge doses of metals in pretreated mice when compared with that in nonpretreated control.

\section{RESUlts}

Experiment I. Mortality change by pretreatment

Small dose (one tenth of challenge dose) of each metal was administered intraperitoneally to mice, and $24 \mathrm{hr}$ later challenge dose (about 70-80\% lethal doses) of the same metal was injected intraperitoneally. Mortality with in 7 days after injection was compared with that of nonpretreated mice injected challenge dose.

The experimental results were shown in Table 1. For example, mice which

Table 1 . Mortality change by pretreatment.

\begin{tabular}{|c|c|c|c|c|c|}
\hline & & \multicolumn{2}{|c|}{ Administered dose } & \multicolumn{2}{|c|}{7 Days mortality } \\
\hline & & $\begin{array}{l}\text { Pretreatment } \\
\mathrm{mg} / \mathrm{kg}\end{array}$ & $\begin{array}{c}\text { Challenge } \\
\mathrm{mg} / \mathrm{kg}\end{array}$ & Pretreated & Non-pretreated \\
\hline \multirow[t]{8}{*}{ I } & $\mathrm{Ag}$ & 3.5 & 35 & $3 / 10$ & $8 / 10$ \\
\hline & As & 1.0 & 11 & $4 / 10$ & $8 / 10$ \\
\hline & $\mathrm{Cd}$ & 0.6 & 6 & $2 / 10$ & $8 / 10$ \\
\hline & $\mathrm{Hg}$ & 0.4 & 4 & $2 / 10$ & $7 / 10$ \\
\hline & In & 0.8 & 4 & $2 / 10$ & $7 / 10$ \\
\hline & $\mathrm{Mn}$ & 5.0 & 50 & $0 / 10$ & $6 / 10$ \\
\hline & $\mathrm{Pb}$ & 10.0 & 100 & $0 / 10$ & $6 / 10$ \\
\hline & $\mathrm{Sn}$ & 2.0 & 25 & $2 / 10$ & $6 / 10$ \\
\hline \multirow[t]{4}{*}{ II } & $\mathrm{Cu}$ & 0.5 & 5 & $8 / 10$ & $8 / 10$ \\
\hline & $\mathrm{Ni}$ & 2.5 & 25 & $7 / 10$ & $8 / 10$ \\
\hline & $\mathrm{Se}$ & 0.6 & 6 & $6 / 10$ & $5 / 10$ \\
\hline & $\mathrm{T} 1$ & 3.5 & 30 & $9 / 10$ & $9 / 10$ \\
\hline \multirow[t]{4}{*}{ III } & $\mathrm{Ba}$ & 2.5 & 25 & $6 / 10$ & $2 / 10$ \\
\hline & $\mathrm{Cr}$ & 12.0 & 120 & $9 / 10$ & $4 / 10$ \\
\hline & $\mathrm{Fe}$ & 4.5 & 45 & $5 / 10$ & $2 / 10$ \\
\hline & $\mathrm{Zn}$ & 2.0 & 20 & $9 / 10$ & $0 / 10$ \\
\hline
\end{tabular}

Small doses of metals were injected intraperitoneally in mice (pretreatment), $24 \mathrm{hr}$ later challenge doses of the same metals were injected intraperitoneally. 


\section{H. YOSHIKAWA}

had been pretreated with $0.6 \mathrm{mg} / \mathrm{kg}$ of $\mathrm{Cd}$ died only 2 out of 10 after receiving challenge dose of $6 \mathrm{mg} / \mathrm{kg}$ of $\mathrm{Cd}$, while nonpretreated mice which were injected with $6 \mathrm{mg} / \mathrm{kg}$ of $\mathrm{Cd}$ died 8 out of 10 . This indicates that $\mathrm{Cd}$ can produce a tolerance against its own toxic action. The data in Table 1 indicates that a tolerance similar to that found with $\mathrm{Cd}$ was also established with $\mathrm{Ag}, \mathrm{As}, \mathrm{Hg}, \mathrm{In}, \mathrm{Mn}, \mathrm{Pb}$, and $\mathrm{Sn}$.

On the contrary, with metals such as $\mathrm{Ba}, \mathrm{Cr}, \mathrm{Fe}$, and $\mathrm{Zn}$, pretreatment in small doses caused an increase in mortality from challenging of the same metals. For example, the mice pretreated with $2 \mathrm{mg} / \mathrm{kg}$ of $\mathrm{Zn}$ died 9 out of 10 with injection of $20 \mathrm{mg} / \mathrm{kg}$ of $\mathrm{Zn}$, while all mice injected with $20 \mathrm{mg} / \mathrm{kg}$ of $\mathrm{Zn}$ survived. This shows that acute toxicity of these metals was increased with pretreatment.

In the case of metals such as $\mathrm{Cu}, \mathrm{Ni}$, Se, and $\mathrm{Tl}$, there were no change in mortality from challenging in mice with or without pretreatment.

From these results, it is clear that metals can be divided into 3 groups from the viewpoint of the tolerance reactions.

\section{Experiment 2. Relationship between the route of administration and tolerance}

In Experiment 1, metal for pretreatment and challenging were introduced into the peritoneal cavity in mice, and there is a possibility that the tolerance acquired

Table 2. Mortality change by changing administration method of pretreatment.

\begin{tabular}{|c|c|c|c|c|c|}
\hline \multicolumn{2}{|c|}{ Pretreatment } & \multirow{2}{*}{$\begin{array}{l}\text { Interval between } \\
\text { pretreatment and } \\
\text { challenge (hr) }\end{array}$} & \multicolumn{2}{|c|}{$\begin{array}{l}\text { Challenge } \\
\mathrm{mg} / \mathrm{kg} \text {, IP }\end{array}$} & \multirow{2}{*}{$\frac{7 \text { Days mortality }}{8 / 10}$} \\
\hline $\mathrm{Cd}$ & $6 \mathrm{mg} / \mathrm{kg} \quad \mathrm{IP}^{*}$ & & & & \\
\hline $0.9 \% \mathrm{NaCl}$ & $0.2 \mathrm{cc} \quad \mathrm{IP}$ & 24 & $\mathrm{Cd}$ & 6 & $8 / 10$ \\
\hline $10 \%$ Dextrose & $0.2 \mathrm{cc} \quad$ IP & 24 & $\mathrm{Cd}$ & 6 & $7 / 10$ \\
\hline $\mathrm{Cd}$ & $0.6 \mathrm{mg} / \mathrm{kg} \quad$ IP & 24 & $\mathrm{Cd}$ & 6 & $2 / 10$ \\
\hline $\mathrm{Cd}$ & $1.2 \mathrm{mg} / \mathrm{kg} \mathrm{SC} * *$ & 24 & $\mathrm{Cd}$ & 6 & $4 / 10$ \\
\hline $\mathrm{Cd}$ & $10 \mathrm{mg} / \mathrm{kg}$ Oral & 24 & $\mathrm{Cd}$ & 6 & $4 / 10$ \\
\hline $\mathrm{Pb}$ & $100 \mathrm{mg} / \mathrm{kg} \quad$ IP & & & & $6 / 10$ \\
\hline $\mathrm{Pb}$ & $10 \mathrm{mg} / \mathrm{kg} \quad$ IP & 72 & $\mathrm{~Pb}$ & 100 & $1 / 10$ \\
\hline $\mathrm{Pb}$ & $10 \mathrm{mg} / \mathrm{kg} \quad \mathrm{SC}$ & 72 & $\mathrm{~Pb}$ & 100 & $1 / 10$ \\
\hline $\mathrm{Pb}$ & $50 \mathrm{mg} / \mathrm{kg}$ Oral & 72 & $\mathrm{~Pb}$ & 100 & $2 / 5$ \\
\hline In & $4 \mathrm{mg} / \mathrm{kg} \quad$ IP & & & & $7 / 10$ \\
\hline In & $0.8 \mathrm{mg} / \mathrm{kg} \quad$ IP & 24 & In & 4 & $2 / 10$ \\
\hline In & $1 \mathrm{mg} / \mathrm{kg} \quad \mathrm{SC}$ & 24 & In & 4 & $0 / 5$ \\
\hline In & $4 \mathrm{mg} / \mathrm{kg}$ Oral & 24 & In & 4 & $2 / 5$ \\
\hline $\mathrm{Hg}$ & $4 \mathrm{mg} / \mathrm{kg} \quad$ IP & & & & $7 / 10$ \\
\hline $\mathrm{Hg}$ & $0.4 \mathrm{mg} / \mathrm{kg} \quad$ IP & 24 & $\mathrm{Hg}$ & 4 & $2 / 10$ \\
\hline $\mathrm{Hg}$ & $0.8 \mathrm{mg} / \mathrm{kg} \mathrm{SC}$ & 24 & $\mathrm{Hg}$ & 4 & $1 / 10$ \\
\hline $\mathrm{Hg}$ & $1 \mathrm{mg} / \mathrm{kg}$ Oral & 24 & $\mathrm{Hg}$ & 4 & $2 / 5$ \\
\hline
\end{tabular}

* IP: Intraperitoneal injection.

** SC: Subcutaneous injection. 


\section{EFFECT OF PRETREATMENT ON METAL TOXICITY}

by pretreatment may take place as a local reaction in intraperitoneal cavity. The Experiment 2 was designed to examine whether this tolerance can be produced when the route of administration for pretreatment was changed.

$\mathrm{Cd}, \mathrm{Hg}$, In, and $\mathrm{Pb}$ were respectively administered to mice intraperitoneally, subcutaneously, and orally as pretreatment, and each metal was injected to them intraperitoneally as challenge. To examine the injection effect of pretreatment, another groups of mice were injected with dextrose or $0.9 \% \mathrm{NaCl}$ solution intraperitoneally and then challenged by $\mathrm{Cd}$ intraperitoneally.

As shown in Table 2, pretreatment by any administration route caused a decrease in the mortality produced by challenge of metal whereas pretreatment with dextrose and $0.9 \% \mathrm{NaCl}$ had no such effect. This result shows that the tolerance acquired by the pretreatment of these metals was not a result of local reaction but a result of systemic reaction.

\section{Experiment 3. Dosage of metals needed for the acquisition of tolerance}

This experiment was performed to determine the dosage of metal needed for development of tolerance. One half, one fifth, one tenth, one twentieth, one fiftieth, and one hundredth of challenge dose were used as pretreatment dosage and 24

Table 3. Metal doses needed for the acquisition of tolerance.

\begin{tabular}{|c|c|c|c|c|c|}
\hline \multicolumn{2}{|c|}{$\begin{array}{l}\text { Pretreatment } \\
\text { mg } / \mathrm{kg}, \mathrm{IP}\end{array}$} & \multicolumn{2}{|c|}{$\begin{array}{l}\text { Challenge. } \\
\mathrm{mg} / \mathrm{kg} \text {, IP }\end{array}$} & \multirow{2}{*}{$\begin{array}{c}\begin{array}{c}\text { Interval } \\
\text { time (hr) }\end{array} \\
24\end{array}$} & \multirow{2}{*}{$\frac{7 \text { Days mortality }}{5 / 5}$} \\
\hline $\mathrm{Cd}$ & 0.06 & $\mathrm{Cd}$ & 6 & & \\
\hline & 0.12 & & 6 & 24 & $4 / 5$ \\
\hline & 0.3 & & 6 & 24 & $1 / 5$ \\
\hline & 0.6 & & 6 & 24 & $1 / 5$ \\
\hline & 1.2 & & 6 & 24 & $0 / 5$ \\
\hline & 3.0 & & 6 & 24 & $0 / 5$ \\
\hline \multirow[t]{5}{*}{$\mathrm{Pb}$} & 1.0 & $\mathrm{~Pb}$ & 100 & 72 & $2 / 5$ \\
\hline & 2.0 & & 100 & 72 & $0 / 5$ \\
\hline & 5.0 & & 100 & 72 & $1 / 5$ \\
\hline & 10.0 & & 100 & 72 & $0 / 5$ \\
\hline & 20.0 & & 100 & 72 & $3 / 5$ \\
\hline \multirow[t]{6}{*}{ In } & 0.04 & In & 4 & 24 & $5 / 5$ \\
\hline & 0.08 & & 4 & 24 & $2 / 5$ \\
\hline & 0.2 & & 4 & 24 & $1 / 5$ \\
\hline & 0.4 & & 4 & 24 & $1 / 5$ \\
\hline & 0.8 & & 4 & 24 & $0 / 5$ \\
\hline & 2.0 & & 4 & 24 & $5 / 5$ \\
\hline \multirow[t]{5}{*}{$\mathrm{Hg}$} & 0.04 & $\mathrm{Hg}$ & 4 & 24 & $2 / 5$ \\
\hline & 0.08 & & 4 & 24 & $1 / 5$ \\
\hline & 0.2 & & 4 & 24 & $0 / 5$ \\
\hline & 0.4 & & 4 & 24 & $0 / 5$ \\
\hline & 0.8 & & 4 & 24 & $3 / 5$ \\
\hline
\end{tabular}




\section{H. YOSHIKAWA}

hr later challenge dose was injected intraperitoneally.

As seen in Table 3, pretreatment dose with 0.3 to $3.0 \mathrm{mg} / \mathrm{kg}$ of $\mathrm{Cd}(1 / 20$ to $1 / 2$ of challenge dose), 2 to $10 \mathrm{mg} / \mathrm{kg}$ of $\mathrm{Pb}$ ( $1 / 50$ to $1 / 10$ of challenge dose), 0.08 to $0.4 \mathrm{mg} / \mathrm{kg}$ of $\mathrm{Hg}$ (1/50 to $1 / 10$ of challenge dose), and 0.2 to $0.8 \mathrm{mg} / \mathrm{kg}$ of In (1/ 20 to $1 / 5$ of challenge dose) had the ability to promote the tolerance against challenge administration. That is, the dosage of metal needed for the acquisition of tolerance was more or less different for each metal, but generally these data indicate that one tenth to one twentieth of lethal doses was needed for the acquisition of tolerance.

\section{Experiment 4. The onset and duration of tolerance}

The onset of tolerance to challenging of metals and its duration after the pretreatment on mice were investigated.

A challenge dose was injected at random within 14 days after pretreatment and results are shown in Table 4 . The tolerance developed within 24 to $48 \mathrm{hr}$

Table 4. Change of mortality by the interval between pretreatment and challenge.

\begin{tabular}{|c|c|c|c|c|}
\hline \multicolumn{2}{|c|}{$\begin{array}{l}\text { Pretreatment } \\
\mathrm{mg} / \mathrm{kg} \text {, IP }\end{array}$} & $\begin{array}{c}\text { Interval } \\
\text { times } \\
\text { (days) }\end{array}$ & $\begin{array}{l}\text { Challenge } \\
\mathrm{mg} / \mathrm{kg} \text {, IP }\end{array}$ & 7 Days mortality \\
\hline \multirow[t]{5}{*}{$\mathrm{Cd}$} & 1.2 & 1 & 6 & $2 / 10$ \\
\hline & 1.2 & 2 & 6 & $2 / 10$ \\
\hline & 1.2 & 3 & 6 & $5 / 10$ \\
\hline & 1.2 & 5 & 6 & $9 / 10$ \\
\hline & 1.2 & 7 & 6 & $8 / 10$ \\
\hline \multirow[t]{7}{*}{$\mathrm{Pb}$} & 10 & 1 & 100 & $4 / 10$ \\
\hline & 10 & 2 & 100 & $1 / 10$ \\
\hline & 10 & 3 & 100 & $1 / 10$ \\
\hline & 10 & 4 & 100 & $1 / 10$ \\
\hline & 10 & 7 & 100 & $0 / 10$ \\
\hline & 10 & 10 & 100 & $0 / 10$ \\
\hline & 10 & 14 & 100 & $2 / 5$ \\
\hline \multirow[t]{6}{*}{ In } & 0.8 & 1 & 4 & $2 / 10$ \\
\hline & 0.8 & 2 & 4 & $2 / 10$ \\
\hline & 0.8 & 4 & 4 & $0 / 5$ \\
\hline & 0.8 & 7 & 4 & $1 / 10$ \\
\hline & 0.8 & 10 & 4 & $0 / 5$ \\
\hline & 0.8 & 14 & 4 & $2 / 5$ \\
\hline \multirow[t]{6}{*}{$\mathrm{Hg}$} & 0.4 & 1 & 4 & $3 / 5$ \\
\hline & 0.4 & 2 & 4 & $0 / 5$ \\
\hline & 0.4 & 4 & 4 & $0 / 5$ \\
\hline & 0.4 & 7 & 4 & $0 / 5$ \\
\hline & 0.4 & 10 & 4 & $0 / 5$ \\
\hline & 0.4 & 14 & 4 & $4 / 5$ \\
\hline
\end{tabular}




\section{EFFECT OF PRETREATMENT ON METAL TOXICITY}

after pretreatment, though this period of time was more or less different for each metal. The tolerance by $\mathrm{Cd}$ and In was acquired within $24 \mathrm{hr}$, while that by $\mathrm{Hg}$ and $\mathrm{Pb}$ was produced within $48 \mathrm{hr}$.

The duration of tolerance after the pretreatment of mice with metals was found to be generally measurable for 10 to 14 days as seen in Table 4, whereas tolerance for Cd lasted only for 3 days.

\section{Experiment 5. Cross-tolerance}

The tolerance development was studied in mice when the challenge metal was different from the pretreatment metal (cross-tolerance).

The combination of metals was at random. As shown in Table 5, the crosstolerance generally appeared among metals which had been recognized to produce the tolerance in Experiment 1. This result of cross-tolerance indicates that the tolerance mechanism is nonspecific, though these metals have the varied physicochemical reactivity. However, it must be noted that the combination of $\mathrm{Cd}$ and Mn both of which showed the tolerance in Experiment 1, did not induce the crosstolerance.

The metals that did not produce tolerance in Experiment 1 generally did not show the cross-tolerance. Even if the metals which produced tolerance in Experiment 1 were administered as pretreatment, the cross-tolerance did not occur when the metals which did not produce tolerance was injected as challenging.

Table 5. Cross-tolerance among metals.

\begin{tabular}{|c|c|c|c|c|c|}
\hline \multirow{2}{*}{\multicolumn{2}{|c|}{$\begin{array}{l}\text { Pretreatment } \\
\mathrm{mg} / \mathrm{kg} \text {. IP }\end{array}$}} & \multirow{2}{*}{\multicolumn{2}{|c|}{$\begin{array}{l}\text { Challenge } \\
\mathrm{mg} / \mathrm{kg} \text {. IP }\end{array}$}} & \multicolumn{2}{|c|}{7 Days mortality } \\
\hline & & & & \multirow{2}{*}{$\frac{\text { Pretreated }}{2 / 10}$} & \multirow{2}{*}{$\frac{\text { Non-pretreated }}{8 / 10}$} \\
\hline $\mathrm{Hg}$ & 1.0 & $\mathrm{Cd}$ & 6 & & \\
\hline In & 0.8 & $\mathrm{Cd}$ & 6 & $2 / 10$ & $8 / 10$ \\
\hline $\mathrm{Hg}$ & 1.0 & In & 8 & $4 / 10$ & $10 / 10$ \\
\hline In & 0.8 & $\mathrm{~Pb}$ & 100 & $2 / 10$ & $6 / 10$ \\
\hline $\mathrm{Cd}$ & 0.6 & $\mathrm{Cu}$ & 5 & $4 / 10$ & $8 / 10$ \\
\hline $\mathrm{Mn}$ & 7.0 & $\mathrm{Cd}$ & 6 & $4 / 10$ & $8 / 10$ \\
\hline Mn & 7.0 & In & 8 & $4 / 10$ & $10 / 10$ \\
\hline $\mathrm{Mn}$ & 7.0 & $\mathrm{Cu}$ & 5 & $2 / 10$ & $8 / 10$ \\
\hline $\mathrm{Cd}$ & 0.6 & $\mathrm{Zn}$ & 20 & $3 / 5$ & $0 / 10$ \\
\hline $\mathrm{Hg}$ & 1.0 & $\mathrm{Zn}$ & 20 & $3 / 5$ & $0 / 10$ \\
\hline $\mathrm{Cd}$ & 0.6 & $\mathrm{Mn}$ & 50 & $4 / 10$ & $6 / 10$ \\
\hline $\mathrm{Cu}$ & 0.5 & $\mathrm{Hg}$ & 6 & $4 / 5$ & $5 / 5$ \\
\hline $\mathrm{Zn}$ & 2.0 & $\mathrm{Cu}$ & 5 & $5 / 5$ & $8 / 10$ \\
\hline Mn & 7.0 & $\mathrm{Zn}$ & 20 & $2 / 5$ & $0 / 5$ \\
\hline
\end{tabular}

Interval time between pretreatment and challenge is $24 \mathrm{hr}$. 


\section{H. YOSHIKAWA}

\section{Discussion}

The present data indicates that mice administered with small doses of metal can develop a tolerance to the subsequent challenge of the same metal and also produce a cross-tolerance among many metals.

Recently, Kato et $a l^{6}$ ) have reported that the damage inducing effect of cadmium on the testis in mice was inhibited when they had been treated with a smaller dose of cadmium prior to the administration of effective dose of cadmium, and the author ${ }^{17)}$ has also confirmed this fact. Gabbiani $e t a l^{7)}$ have reported that a pretreatment with cadmium and cobalt inhibited sensory ganglia lesion induced by cadmium whereas pretreatment with nickel and iron had no such effect. The present data also showed that pretreatment with cadmium and mercury has an ability to produce a tolerance against their own toxic action, but on the contrary, nickel and iron have no ability to develop a tolerance. Parizek et al ${ }^{8)}$ have reported that injection of selenite proved to be a highly protective agent in sublimate intoxication, even when the injection of selenite was given $1 \mathrm{hr}$ after injection of sublimate.

The trace metals found in mammals are divided into 2 groups $^{18)}$ : metals considered to be essential for mammals (essential metals) and metals usually not detected in infant but present in adult and apparently acquired and accumulated from environmental contaminants (contaminant metals).

From this classification and the present experiments, the followings may be deduced. Most metals that have an ability to develop a tolerance belong to the contaminant metals, and metals that do not produce a tolerance belong to the essential metals. Metals such as zinc and iron which are present in a large quantity in the body not only produce tolerance but promote the reaction. Therefore, the metals may be divided into 3 groups from the viewpoint of tolerance, though they are divided into 2 groups from the viewpoint of biological necessity.

Most of metals which developed the tolerance can induce the cross-tolerance, but the metals which do not induce the tolerance do not produce the cross-tolerance. These results indicate, though this tolerance mechanism is still unknown, that the tolerance mechanism is nonspecific, though these metals vary in physicochemical property.

From the fact that selenite is highly effective for preventing selective toxic effect of mercury and cadmium, Parizek et $a l^{8)}$ described its possibility as follows: The protective effect of selenium could be a result of some change in the distribution of mercury and cadmium in the organs, or in the chemical form in which mercury and cadmium is present, or in the sensitivity of organs to the toxic effect of bivalent cation by some other means. Baumann et $a l^{2 \sim 4)}$ have found some change in selenium distribution and excretion as a result of administration of arsenic and cadmium. Gunn et $a l^{9)}$ have reported that cadmium interferes with fecal excretion 


\section{EFFECT OF PRETREATMENT ON METAL TOXICITY}

of zinc, resulting in an increased retention of zinc in liver, kidney, and pancreas. Van Campen ${ }^{5)}$ reported about the effect of zinc, cadmium, silver, and mercury on the absorption and distribution of copper. Chaika ${ }^{11)}$ has described, in the study of chronic lead poisoning by simultaneous administration of cobalt or copper, that cobalt inhibited the development of anemia caused by lead poisoning and abolished the inhibitory effect of lead to the growth whereas copper had no such effect. Bunn et $a l^{10)}$ reported, in the experiment of chronic cadmium poisoning by simultaneous administration of copper or zinc, that supplementary zinc significantly decreased cadmium and increased iron in liver, also supplementary copper had a higher concentration of cadmium and zinc in liver and a lower concentration of iron in liver.

These reports may suggest an interaction among metals in body, though the tolerance mechanism and factors are still unknown. However, as seen from the present data, the fact that metals are divided into 3 groups from their tolerance reaction seems to be necessary on the consideration of metal interaction in body.

\section{REFERENCES}

1. White, M.R. and Schubert, J. (1952). J. Pharmacol. Exptl. Therapy, 104, 317.

2. Ganther, H.E. and Baumann, C. A. (1962). J. Nutr., 77, 210.

3. Levander, O. A. and Baumann, C. A. (1966). Toxicol. Appl. Pharmacol., 9, 98.

4. Levander, O. A. and Baumann, C. A. (1966). Toxicol. Appl. Pharmacol., 9, 106.

5. Van Campen, D. R. (1966). J. Nutr., 88, 125.

6. Ito, T. and Sawauchi, K. (1966). Okajimas Fol. Anat. Jap., 42, 107.

7. Gabbiani, G., Baic, D., and Deziel, C. (1967). Can. J. Physiol. Pharmacol., 45, 443.

8. Parizek, J. and Ivana Ostadalova (1967). Experientia, 23, 142.

9. Gunn, S. A., et al. (1962). Proc. Soc. Exptl. Biol. Med., 111, 559.

10. Bunn, C. R. and Matrone, G. (1966). J. Nutr., 90, 395.

11. Chaika, P. A. (1968). Vop. Pitan., 27, 29. (refer to Sci. Labour (1969). 45, 275 (in Japanese)).

12. Cohen, A.E. et al. (1959). Am. Ind. Hyg. Assoc. J., 20, 303.

13. Yoshikawa, H., et al. (1965). Japan. J. Ind. Health, 7, 685. (in Japanese).

14. Scheel, L. D. (1965). Am. Ind. Hyg. Assoc. J., 26, 585.

15. Dixon, J. R., et al. (1966). Toxicol. Appl. Pharmacol., 9, 225.

16. Yoshikawa, H. (1968). Ind. Health, 6, 88.

17. Yoshikawa, H. (1969). Med. Biol. (Tokyo), 78, 19. (in Japanese).

18. Schroeder, H. A. (1960). Metal-Binding In Medicine. (Edited by Seven, M.J.) Lippincott, Philadelphia. 59. 